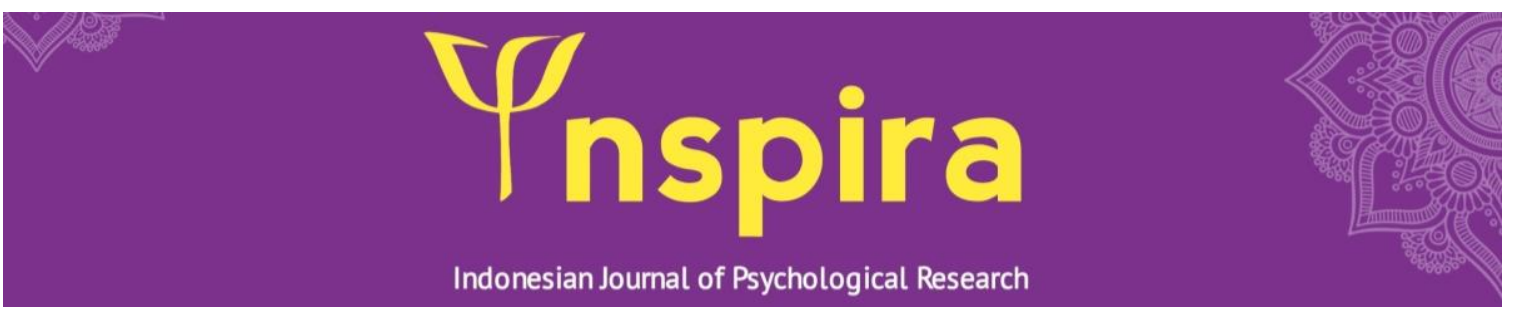

\title{
The assertiveness of Acehnese and Javanese university students
}

\author{
Martini $^{1}$, Syiva Fitria ${ }^{2 \varpi}$
}

${ }^{1}$ Department of Psychology Department, Universitas Malikussaleh, Indonesia;

${ }^{2}$ Department of Islamic Guidance and Counseling Department, Institut Agama Islam Negeri Langsa, Indonesia

\section{${ }^{\square}$ Corresponding author:}

Syiva Fitria (email: syivafitria@iainlangsa.ac.id)

\begin{abstract}
The current study aims to determine the differences in the Javanese and Acehnese students of the psychology study program at the Malikussaleh University. This study used descriptive quantitative methods. The participants were 30 active students, equally from Acehnese and Javanese ethnic backgrounds of the psychology study program at the Malikussaleh University recruited using a purposive random sampling technique. The data collected by using the assertive behavior scale. Data analysis used statistical analysis of the Independent sample T-test. The results of this study indicate that there was no differences in assertiveness between Javanese $(M=66,93, S D=3,474)$ and Acehnese $(M=67,67, S D=4,254)(t=0.527, p \geq 0.005)$
\end{abstract}

Article History:

Received: June 24, 2021

Revised: June 25, 2021

Accepted: June 30, 2021

Published: June 30, 2021

\section{Keyword:}

assertiveness; Acehnese;

Javanese; university

students

\section{How to cite (APA $7^{\text {th }}$ Edition)}

Martini, M., \& Fitria, S. (2021). The assertiveness of Acehnese and Javanese university students. INSPIRA: Indonesian Journal of Psychological Research, 1(1), 1-4. https://doi.org/10.32505/inspira.v2i1.2956

This is an open-access article distributed under the Creative Commons Attribution License, which permits unrestricted use, distribution, and reproduction in any medium provided the original work is properly cited. This is enabled under the terms of attribution and noncommercial usage of the material (C2021 by Martini \& Syiva Fitria 


\section{INTRODUCTION}

Assertiveness is the individual ability to communicate one's thoughts confidently without being aggressive (Comstock, 2020). Being assertive indicates an individual with high self-esteem through communicating needs or preferences to the other party. Alberti and Emmons (1974) define assertive individuals as individuals who self-assuredly express their stances and act decisively. Assertive is the ability being able to communicate though, feelings, and desires. Being assertive requires honesty with oneself and honesty in expressing feelings, opinions, and needs proportionately without manipulation. According to Llyod (1991), assertive behavior is honest and active behavior in which one can express opinions to others and respect for himself and others.

Furthermore, Atkinson (1997) stated that assertive behavior is where a state of mind also has specific verbal and non-verbal communication skills. Assertiveness is about having thoughts and carrying out those thoughts without any coercion. However, assertiveness should not be confused with an aggressive attitude, and assertiveness is honest, objective, not influenced by judgments or emotional things.

Correspondingly, Lioyd (1991) states that there are several assertive characteristics. The first is being able to say no politely and firmly. The second is being able to express honest feelings. The third is that individuals will speak following reality and honestly with others, and the last can express preferences and priorities. Thus, assertiveness is behavior that shows the ability to express what is wanted, felt, and thought to others but still maintains and respects the rights and feelings of others.

Crassini, Law, \& Wilson (1979) analyze the gender effect in assertiveness, resulting in no significant differences between males' and females' levels of assertiveness. However, Llyod (1991) argued that assertiveness is influenced by gender. Since childhood, the roles and education of men and women have been differentiated by society and customizing that boys must be assertive and competitive, while girls must be passive and sensitive, resulting in boys behaving more assertively than girls. Furthermore, There were many studies have been conducted on assertiveness. A study conducted by Surya, Menanti, \& Siregar (2018) explores the effects of educators' assertive behavior on the anxiety experienced by foreign language students. Additionally, Filippello et al. (2014) also examined the relationship between assertive behavior and frustration intolerance, and unhealthy emotions. So, assertiveness is an aspect that occurs in various fields.

Nevertheless, the current study intended to analyze the cross-culture effect on assertiveness as a previous study known as the GLOBE study argued that assertiveness is one of 9 dimensions of culture (House et al., 2004). Furthermore, Calza, Aliane, \& Cannavale (2010) conducted a study that culture powerfully influenced assertiveness and determined the success of Italian managers in managing Algerian employees who are low in assertiveness.

Additionally, previous research found that assertiveness influences adjustment. A study with university students by Parmaksiz (2019) found that university student level of assertiveness determined students' adjustment in many aspects, specifically emotional adjustment, personal adjustment, adjustment to the opposite sex, social adjustment, academic adjustment, and adjustment in general. Therefore, this study aims to analyze the differences in assertiveness between Acehnese and Javanese university students. 


\section{RESEARCH METHOD}

The current study was quantitative descriptive research. The participants of this study were 30 university students with Acehnese and Javanese ethnic backgrounds from Malikulssaleh University. The participants were recruited using purposive random sampling and participated in this study voluntarily and consciously. This research was conducted for one month and two weeks, from October 2019 to November 2019. The data was collected using questionnaires consist of demographic information items and a 29-items Likert scale on assertiveness. The collected data was analyzed using SPSS 23.0 statistic software. An independent sample t-test was performed to analyzed the difference in assertiveness between the two groups.

\section{RESULT}

Independent Samples T-Test was used to assess whether there was a difference between a group of independent samples. Based on this analysis, it is known that in the assertive variable, there is no difference between the assertiveness of the Javanese and the Acehnese $(t=.527, p \geq$ .005). That Javanese's assertiveness $(M=66,93, S D=3,474)$ is similar the acehnese's assertive $(M=67,67, S D=4,254)$.

Table 1 Levene's test result

\begin{tabular}{ccc}
\hline $\mathrm{F}$ & $\mathrm{p}$-value & $\mathrm{t}$ \\
\hline 0,071 & 0,792 & $-0,517$ \\
\hline
\end{tabular}

Based on the output above, it is known that the value of Sig. Levene's Test for Equality of Variances is $0.792>0.05$, which means that the data variance between the Javanese and the Acehnese is homogeneous (V. Wiratna Sujarweni, 2014: 99) so that the interpretation of the Independent Samples Test output table above is guided by the values contained in the Equal Variances Assumed table.

Based on the Independent Samples Test output table in the Equal Variances Assumed section, Sig's value is known. (2-tailed) of $0.609>0.05$. So as the basis for decision making in the Independent Samples Test, it can be concluded that $\mathrm{Ha}$ is rejected and Ho is accepted. Thus it can be concluded that the significant value in the $\mathrm{F}$ test is 0.792 greater than 0.05 , so Ho is accepted. So, it can be concluded that the two tribes between Java and Aceh are the same. With this test, the T-test uses Equal Variances Assumed (assuming that both variants are the same).

\section{DISCUSSION}

The purpose of this study was to determine whether there were differences in assertive behavior between Javanese and Acehnese on psychology students at Malikussaleh University. This research was conducted by using quantitative research methods through Likert scale questionnaires for data collection.

The research found that there were no differences in assertiveness between Javanese and Acehnese students. This finding contradicts with the previous study that stated culture, especially 
tribes in assertiveness, such as the study conducted with Italian manager with Algerian staff that implicitly stated there different in the assertiveness of Algerian that increases the assertiveness of manager (Calza, Aliane, \& Cannavale, 2010)

However, since this study was conducted with a small number of participants, future research needed a larger sample to analyze the cultural differences of assertiveness. Further research is also recommended in assessing how assertiveness influencing university students' behavior.

\section{CONCLUSION}

Based on the results obtained, it can be concluded that the assertiveness between the two tribes, Javanese, and Acehnese, is similar.

\section{REFERENCES}

Atkinson, J. M. (1997). Pengantar psikologi (Edisi kesebelas Jilid satu). Interaksara.

Alberti, R. E., \& Emmons, M. L. (1974). Your perfect right: a guide to assertive behavior. 2d ed. Impact.

Calza, F., Aliane, N. \& Cannavale, C. (2010). Cross-cultural differences and Italian firms' internationalization in Algeria: Exploring assertiveness and performance orientation. European Bussiness Review, 22 (2), 246-272

Comstock, Nancy W. (2020). Assertiveness. Salem Press Encyclopedia. Retrieved May 2019 from http://0-

search.ebscohost.com.biblio.url.edu/login.aspx?direct=true\&db=ers\&AN=100259209\&lang= es\&site $=$ eds-live.

Crassini, B., Law, H. G., \& Wilson, E. (1979). Sex differences in assertive behaviour? Australian Journal of Psychology, 31(1), 15-19.

Filippello, P., Harrington, N., Buzzai, C., Sorrenti, L., \& Costa, S. (2014). The relationship between frustration intolerance, unhealthy emotions, and assertive behaviour in Italian students. Journal of Rational-Emotive \& Cognitive-Behavior Therapy, 32(4), 257-278.

House, R.J., Hanges, P.J., Javidan, M., Dorfman, P.W. \& Gupta, V. (eds) (2004) Culture, leadership, and organizations. Sage.

Lloyd, S. R. (1991). Mengembangkan Perilaku Asertifyang Positif. (Terjemahan). Binarupa Aksara

Parmaksız, i. (2019). Assertiveness as the predictor of adjustment to university life amongst university students. International Journal of Instruction, 12(4), 131-148. https://doi.org/10.29333/iji.2019.1249a

Surya, D., Menanti, A., \& Siregar, N. S. S. (2018). The relationship between self-efficacy and lecturer's assertive behavior with foreign language anxiety. ENLIGHTEN: Jurnal Bimbingan Konseling Islam, 1(2), 150-164. https://doi.org/10.32505/enlighten.v1i2.784 